\title{
Forensic investigation, truth and trust in the context of transitional justice in Brazil
}

Marco Aurelio Guimarães University of São Paulo - Ribeirão Preto

mag@fmrp.usp.br

Raffaela Arrabaça Francisco University of São Paulo Ribeirão Preto

raffaela.francisco@gmail.com

Sergio Britto Garcia University of São Paulo - Ribeirão Preto

Martin Evison Northumbria University martin.evison@northumbria.ac.uk

Maria Eliana Castro Pinheiro Independent Group of Families of Political Dead and Disappeared from Brazilian Civil-Military Dictatorship

mecp50@hotmail.com

lara Xavier Pereira Comitê pela Verdade, Memória e Justiça do Distrito Federal

Diva Santana Independent Group of Families of Political Dead and Disappeared from Brazilian Civil-Military Dictatorship santanadiva13@gmail.com

Julie Alvina Guss Patrício Independent Group of Families of Political Dead and Disappeared from Brazilian Civil-Military Dictatorship pagualju@yahoo.com.br

\section{Abstract}

Truth commissions are widely recognised tools used in negotiation following political repression. Their work may be underpinned by formal scientific investigation of human remains. This paper presents an analysis of the role of forensic investigations in the transition to democracy following the Brazilian military governments of 1964-85. It considers practices during the dictatorship and in the period follow- 
ing, making reference to analyses of truth commission work in jurisdictions other than Brazil, including those in which the investigation of clandestine burials has taken place. Attempts to conceal the fate of victims during the dictatorship, and the attempts of democratic governments to investigate them are described. Despite various initiatives since the end of the military government, many victims remain unidentified. In Brazil, as elsewhere, forensic investigations are susceptible to political and social influences, leading to a situation in which relatives struggle to obtain meaningful restitution and have little trust in the transitional justice process.

Key words: truth commission, transitional justice, Brazil, forensic science, humanitarian

\section{Introduction}

A period of military government arose in Brazil following a 1964 coup d'état and ended in 1985 with the civil presidency of José Sarney and subsequent direct presidential elections held in 1989. The process of liberalisation was underpinned by the introduction of amnesty laws preventing prosecutions for political crimes committed during the dictatorship era. As the transition to democracy progressed, public pressure led to governmental inquiries into alleged homicides and other human rights abuses - in some instances following on from existing investigations driven by relatives of the disappeared. Forensic science has played a central role in investigations intended to locate and identify victims' remains and establish the events surrounding their deaths. These searches have proved sporadic and unproductive, however, and prosecutions of alleged offenders have been elusive. Representatives of families of the dead and disappeared see the transitional justice process as disingenuous and the amnesty laws as an impediment to due process - a view endorsed by the Inter-American Commission on Human Rights.

Forensic science is commonly perceived to be a powerful tool in criminal investigation and an arbiter of truth in disputes relating to contested events and the identification of individuals. It is important, therefore, to understand the circumstances in which its use has proved to be so fruitless. This article aims to consider the role of forensic investigation of state crime during and following the Brazilian military governments of 1964-85, and the implications for public confidence in transitional and restorative justice in Brazil. This article was written in collaboration between forensic pathologists and anthropologists, and representatives of the Grupo Independente dos Familiares dos Mortos e Desaparecidos Politicos (Independent Group of Families of the Political Dead and Disappeared from Brazilian Civil-Military Dictatorship), all of whom have participated in activities relating to the transitional justice process in Brazil. The article aims to consider this process from these perspectives, focusing on the inquiries in which the authors have been involved - those relating to the Araguaia War, as well as in urban São Paulo, referring to documentary evidence of direct relevance to these inquiries. These include reports of independent and government-sponsored inquiries, official commissions and forensic investigations, excavations and analyses, as well 
as commentary in online news media. While the article makes reference to cases involving named disappeared persons and to specific forensic investigations of alleged clandestine burials, it is not intended to be a quantitative assessment of the use of forensic anthropology in the transitional justice process in Brazil. Rather, it aims to offer an evaluation of the social, legal and political conditions in which forensic human identification is employed, presented by active participants whose perceptions are triangulated with reference to a range of relevant literature.

The article begins by outlining dimensions of the dictatorship and the armed opposition movement. Key elements of the conflict are illustrated using the examples of the Araguaia War in remote Amazonia and the urban resistance in São Paulo (see Figure 1). Concealment of torture and killing in each of these cases is considered, and the nature of subsequent forensic investigations is briefly summarised in the context of newly democratic Brazil. The lack of success in the location and identification of human skeletal remains - a cause of frustration for forensic scientists and relatives of the disappeared alike - is then discussed in relation to the debate regarding the efficacy of transitional justice and the authority of foren-

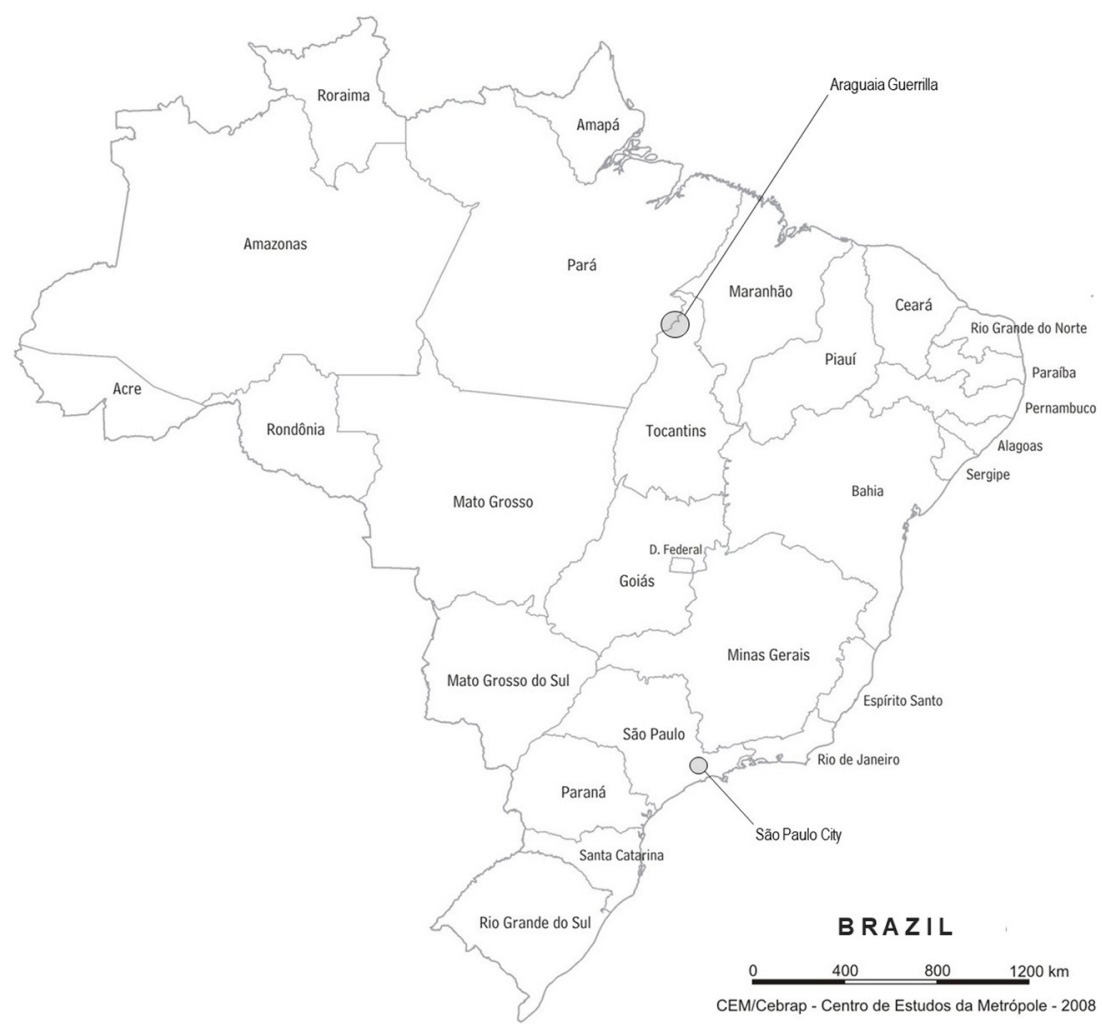

Figure 1 Map showing the location in Brazil of the key sites referred to in the text 
sic science in establishing truth in humanitarian inquiries. The work of Elizabeth Stanley, ${ }^{1}$ who has examined the role of truth commissions in providing recognition to victims of state crime, and Claire Moon's ${ }^{2}$ critique of claims surrounding humanitarian forensic investigation of clandestine burials are introduced. The situation in Brazil is then considered with reference to these and other sources addressing transitional justice and forensic investigations and to literature discussing the role of relatives of the disappeared.

Following Stanley's observations with regard to Chile, South Africa and Timor Leste, and Moon's observations regarding forensic anthropology work in Argentina, we suggest that the process of transitional justice in Brazil is hindered by a variety of operational, social and political factors. The relatively small number of alleged victims in Brazil - most of whom are named - makes the impediments arising from the socio-political context especially striking. While policy makers seek to negotiate conflicting demands, and at the same time obtain public approval for their project, the identities and experiences of most victims remain unrecognised, and the needs of relatives are unmet.

\section{Military government, resistance and response}

A dictatorship was established in Brazil following events of 31 March to 1 April 1964, when President João Goulart was deposed by the military. There was dissatisfaction in some sectors of society with economic instability, high rates of inflation and political chaos. Policies like land reform, nationalisation of petroleum refineries, taxes on the rich and reform of the military were seen as evidence of a possible communist tendency in the government in the middle of the years of the Cold War. Defenders of the military intervention label this historical episode as a revolution or counterrevolution against the 'red menace' - citing the risk of a communist dictatorship similar to that of Cuba. ${ }^{3}$

The military government enjoyed the support of significant parts of Brazilian society, including entrepreneurs, the press and sectors of the church and other institutions who were supportive of the political right - which was aided by the United States government. Historical revisionists consider the term 'civil-military dictatorship' to be a more apt description of the regime. In the opinion of some, Brazil's dictatorship was masked with a democratic appearance in order to reduce social tensions. A succession of five indirectly elected presidents reinforced this perception, and in Brazil there was no 'strongman' comparable to Pinochet in Chile or Videla in Argentina. ${ }^{4}$ Nevertheless, military government led to the suspension and violation of civil and political rights and repression of opponents of the government - mainly belonging to the left-wing political parties. ${ }^{5}$ Although political opponents were frequently tortured and many were killed - or 'disappeared' - a difference between the Brazilian and other dictatorships in Latin America relates to the number of victims. While estimates of those killed range from 3,000-9,800 in Chile to 30,000 in Argentina, in Brazil the official number - based on requests for restitution and compensation - is 437-475. This figure excludes victims unrelated to political parties and those whose families have not made a complaint. Therefore, 
in the absence of empirical studies to indicate otherwise, the real figure may be much higher. ${ }^{6}$

Brazil is a large country $\left(8,515,767 \mathrm{~km}^{2}\right)$ possessing extremes of vast, urban population concentrations and isolated, sparsely populated and extensive wilderness. Armed opposition developed in both urban and remote areas, each emerging with different political and operational dynamics. The Araguaia War in Amazonia and the urban guerrilla movement in São Paulo offer two historically important examples illustrative of fundamental differences in natural and cultural geography, the nature of the armed opposition and the government response.

In São Paulo, armed resistance emerged in the form of the Ação Libertadora Nacional (ALN). Its founder, Carlos Marighella, is credited with authorship of the Urban Guerrilla Manual. ${ }^{7}$ He regarded the urban guerrilla as having a tactical role in distracting the armed forces away from remote areas in order to reduce the intensity of operations against rural guerrillas, who were seen as the means via which to promote socio-political change upwards from the grass roots. The Araguaia Guerrilla War (1966-1974) was the direct result of an insurrection planned by the Partido Comunista do Brasil (PCdoB), with the aim of instigating a socialist revolution in Brazil similar to those of Cuba and China. The movement started in a region of Amazonia known as the Bico do Papagaio (Parrot's Beak), where the states of Pará, Tocantins and Maranhão meet in the locality of Xambioá (Tocantins) and São Geraldo do Araguaia (Pará) on opposite banks of the Araguaia River - covering an area of approximately $7,000 \mathrm{~km}^{2}$. The Araguaia guerrilla group numbered eighty-nine members - sixty-nine from the PCdoB and twenty local to the region. The PCdoB members tended to be drawn from academia and the professions. Students were the most frequently represented group, followed by liberal (medical doctors, nurses, geologists, teachers and lawyers) and other (commercial, banking) professionals. Unskilled workers formed the smallest group. The actual number of participants in the Araguaia War remains uncertain, however, as the guerrillas had the support of a section of the local population, which was also drawn into the conflict. ${ }^{8}$

The response of the government was to send troops to the region, in a deployment which grew to be the second-largest mobilisation of military personnel in Brazil's history, exceeded only by that undertaken during the Second World War. ${ }^{9}$ Three military campaigns were needed to end the Araguaia War, by the end of which all of the guerrillas had been eliminated. Initial efforts by the military, commencing in 1972, were based on conventional tactics involving attempts to saturate the region with troops. Although some guerrillas were killed - as well as some soldiers and farmworkers - this was regarded as an ineffectual strategy: even though more than 10,000 soldiers were deployed, the military forces struggled to supress the insurrection. ${ }^{10}$ A final campaign, from October 1973 to September 1974 , is understood to have been the most aggressive. This was an intelligence-led operation which involved the insertion of members of the military into the local population with the intention to completely exterminate the guerrillas - including the offering of bounties for killing or capture. It is believed that fifteen to twenty guerrillas were arrested, kept alive and then killed after interrogation. Torture, dis- 
memberment, decapitations and executions were commonplace. ${ }^{11}$ It is estimated that more than 500 local people could have been tortured and an unknown number killed, in addition to the official count of $136 .{ }^{12}$ The guerrillas were themselves implicated in torture and killing.

In São Paulo the military government's response was substantially different. Opposition figures were typically arrested or 'snatched' rather than caught in open conflict. They were frequently tortured and killed, but - unlike in remote areas such as Araguaia - the remains were then submitted for a formal autopsy prior to burial in organised cemeteries. ${ }^{13}$ In both cases, however, cynical patterns relating to concealment are evident.

\section{Concealing the crimes}

Of the fifteen guerrilla members who died during the first military campaign in Araguaia, most are believed to have been buried in the local cemetery in Xambioá and others in a municipal cemetery in Marabá (Pará). Remains are believed to have been interred without identification in areas reserved for indigent people. The graves were unmarked, based on the assertion that communists - as atheists - would not accept having a cross placed on their grave and because the guerrillas used code names, which could not be legally used to mark the burial. ${ }^{14}$ The guerrillas killed in the second campaign were also buried in organised rural cemeteries. In the third campaign, burials were reported as taking place in the vicinity of the place where each member was killed - in the middle of the forest or in rural fields. ${ }^{15}$ The remains of local people killed in the conflict are anticipated to have been spread within an area of approximately $7,000 \mathrm{~km}^{2}$, with most probably concentrated in an area between the cities of Xambioá (Tocantins), São Geraldo do Araguaia and Marabá (Pará). Interments in recognised rural cemeteries offered the opportunity for some burials to be located and subsequently investigated. Procedures gradually changed during the military intervention, however, and steps were taken to conceal burials in the rainforest or in military encampments. A formal 'cleaning operation' - operação limpeza - was undertaken in 1975, during which bodies were exhumed from their original places of interment and attempts were made to destroy them by fire or simply by throwing them into the river. ${ }^{16}$ Dismemberment, decapitation and disfigurement were also likely to confound attempts to locate and identify remains.

In urban areas, interment in organised municipal cemeteries was routine, often following a post-mortem examination and the issuing of a death certificate which concealed the real cause of death (see below). In São Paulo a number of victims were buried in Dom Bosco Cemetery. Established in 1971, this is a municipal cemetery in Perus - a locality on the northern edge of the city. ${ }^{17}$ Some victims were interred in individual shallow graves in an area intended for the burial of indigent and unknown persons. Cheap wooden coffins were used, marked with a red ' $\mathrm{T}$ ' for terrorist - on their lids. Other victims were buried in an irregular and illegal common mass grave which also contained the remains of indigent and unidentified people, as well as of suspected or known criminals killed by the 'death squad' - an unofficial force working in parallel with the police which exterminated those 
considered a social problem. There have been indications that bones from individual shallow graves were removed and intentionally mixed with the remains in the mass grave, which has become known as the Vala de Perus - the ditch of Perus. ${ }^{18}$

\section{Finding the evidence?}

In the face of wilful attempts to conceal the crimes of the military dictatorship and the remains of victims, it might be anticipated that the democratic governments of Brazil that have arisen in the thirty-two years since 1985 will have taken steps to identify victims and determine their fate, and offer restitution to relatives.

The role of forensic archaeological and anthropological investigation in the transitional justice process in Brazil has been summarised by Guimarães et al. ${ }^{19}$ Following gradual liberalisation, two new amnesty laws ${ }^{20}$ were implemented between 1961 and 1979, and 1946 and 1988, respectively, exonerating people convicted of political crimes. The civil-military dictatorship officially ended in 1985 and the New Constitution ${ }^{21}$ formally restored civil and human rights.

Between 1995 and 2011 a series of governmental bodies - the Comissão Especial de Mortos e Desaparecidos Políticos or CEMDP (the Special Commission on the Political Dead and Disappeared), ${ }^{22}$ the Secretaria Nacional dos Direitos Humanos or SNDH (the National Human Rights Secretary) ${ }^{23}$ and the Commisão Nacional da Verdade or CNV (National Truth Commission) ${ }^{24}$ were established with the mandate of investigating alleged human rights violations of the military government. Despite, or perhaps as a result of, these initiatives, investigations have progressed slowly and haphazardly.

In Araguaia government-led investigations succeeded those initiated by family members as a consequence of the intervention of the Inter-American Commission on Human Rights, this following a campaign by relatives (whose representatives are included among the co-authors of this article) that began in 1982. Earlier attempts within the various levels of the Brazilian judicial system failed in the face of objections raised based on the controversial Amnesty Law of 1979, which 'extinguished the individual criminal responsibility of both sides involved in the conflict', ${ }^{25}$ and it was only following the enactment of the Amnesty Law that relatives became aware of the extent of the Araguaia Guerrilla War. In 2000 the Inter-American Commission ${ }^{26}$ found that the facts, if confirmed, would find the Brazilian government in violation of Articles I, XXV and XXVI of the American Declaration of the Rights and Duties of Man and Articles 1(1), 4, 8, 12, 13 and 25 of the American Convention on Human Rights, ${ }^{27}$ to which it is a signatory. These articles relate (in summary) to rights to life, liberty and security; due process and a fair trial, equality before the law; and freedom of conscience, religion, thought and expression. ${ }^{28}$ Following an agreement between the First Federal Court of Brasília and the Inter-American Court of Human Rights of the Organisation of American States, investigation in Araguaia finally commenced under the auspices of the Grupo de Trabalha Araguaia or GTA (Araguaia Working Group), ${ }^{29}$ which is now coordinated by the Secretaria de Direitos Humanos da Presidência da República (Human Rights Secretary of the President of the Republic). 
The GTA has undertaken several expeditions to rural Araguaia to which coauthors of this paper have contributed. A number of these have involved the forensic excavation and analysis of skeletal remains, which have been detailed in a series of reports on the investigations. ${ }^{30}$ The GTA reports scrupulously document the topographical and geophysical surveys of the sites, the stratigraphy of the soil at excavation and the circumstances and inventory of any skeletal remains or possessions recovered. The investigative and scientific standards are high and quite comparable to those that would be adopted in a contemporary forensic investigation associated with a homicide involving buried human remains in the United Kingdom, for example. Representatives of the families of the disappeared have attended several of these investigations and been present during excavations of skeletal remains. The thoroughness and transparency of the on-site work is commendable, but contrasts with the ultimate lack of results: of twenty-seven skeletons that have been recovered, none has been identified.

In the urban context, formal autopsy at local medico-legal institutes was repeatedly used to disguise torture and homicide. Exhumations recently requested by the families of the disappeared have revealed the cause of death recorded on death certificates to be false. Evidence of torture and execution has been found. A particularly notorious case is that of opposition journalist Vladimir Herzog, whose body was recovered from a cell in a military institution in São Paulo in 1975. The death certificate originally stated that the cause of death was suicide. A more recent investigation on behalf of the family established evidence of trauma and maltreatment during interrogation, and the death certificate was corrected accordingly. ${ }^{31}$ In a similar case from Belo Horizonte (Minas Gerais), the remains of a political activist, Arnaldo Cardoso Rocha, who was killed during the military government, had been especially well preserved by immersion in water. The original cause of death had been given as due to gunshot wounds following a confrontation with police. An autopsy recently completed at the request of relatives indicated that gunshots had in reality been used to incapacitate and subsequently execute the victim, and that there was further evidence of torture. ${ }^{32}$

In São Paulo the mayor of the city during the military dictatorship years and the then director of the medico-legal institute have been implicated in attempts to conceal the causes of death of the victims - efforts that would have been more effective had a plan to purchase crematory equipment from a British company been successful. ${ }^{33}$ Many autopsies have only recently been granted at the request of relatives, and - commencing in 2012 - at the request of the Commisão Nacional da Verdade and other agencies.

The apparent inability to 'jump the first hurdle' of forensic investigation, that of identification, evident in the GTA investigations, is even more clearly demonstrated in relation to the remains recovered from the Vala de Perus in Dom Bosco Cemetery, São Paulo, where, at the time of writing, remarkably, of 1,049 skeletons discovered in 1990, 1,029 have yet to be investigated: their identities and causes of death remain unknown. Controversy has arisen concerning the policy of the Secretaria Nacional de Direitos Humanos with regard to the Perus investigations. Disagreement regarding the methodology - in particular, lack of focus on DNA 
profiling - with which to investigate the still unanalysed remains has led one university scientific group to withdraw from the work. ${ }^{34}$ A team led by a Peruvian forensic anthropologist has been recruited at some expense (the overall project investment is BRL2.5m) to support the investigation, justified by the claim of a government minister that Brazil does not have sufficient expertise in the area. ${ }^{35}$ Brazilian forensic archaeology and anthropology groups are publicly expressing their frustration at the imposition of a foreign expert on the basis of such a claim, which does seem to stand up to scrutiny. ${ }^{36}$ In reality, the re-emergence of the forensic investigation of human remains in post-dictatorial Brazil was acknowledged in 2003 by the prestigious scientific magazine Nature, ${ }^{37}$ and a forensic anthropology laboratory was established at the University of São Paulo in 2003 with the support of the United Kingdom Foreign and Commonwealth Office. ${ }^{38}$ This laboratory has contributed to regional and national investigations ${ }^{39}$ and research $^{40}$ in forensic anthropology, as well as to the work of the GTA. ${ }^{41}$

Media commentary on the investigation of the material from Perus follows a pattern similar to that of Araguaia, beginning with an investment of resources and another laboratory 'first', ${ }^{42}$ and a series of reports promising identifications as the analysis of the skeletal remains commenced twenty-six years after their discovery. ${ }^{43}$ Progress again appears disappointing, however, and the bones remain unidentified. Changes in municipal and federal administration may affect the financial support sought for the project. ${ }^{44}$

The missing of the era of military government in Brazil are quite unusual in comparison with other conflicts. The numbers of named and acknowledged victims are low - only a little over 400 individuals, with as few as 210 of those still unaccounted for. Therefore, in the cases of both Araguaia and Perus, the identification of remains by DNA analysis and comparison to reference material from the family members of these 210 individuals should be remarkably straightforward, in principle. For some forensic scientists, the lack of progress in identifications in Araguaia and Perus is implausible and inexcusable - and the lack of DNA testing is merely symptomatic, leading to a rejection of the overall programme. ${ }^{45} \mathrm{~A}$ recent TV documentary reporting on the Perus work could be seen as theatre: a series of quiet apologies for a multidisciplinary programme from which no identifications have arisen, but contending optimistically that the work will be a deterrent to future political crimes. ${ }^{46}$ In reality, however, deterrence requires detection. For some relatives, the government-sponsored investigations are little more than exercises that stuff the curricula vitae of the participants - they are not intended or expected to find anything (M. Castro, personal communication).

The conclusion of the Commisão Nacional da Verdade notes that of 434 verified deaths, the remains of only a single individual were located during the course of its work. ${ }^{47}$ Confirmed identifications are restricted to the remains of guerrilla Maria Lúcia Petit, located and exhumed from the cemetery in Xambioá and formally identified by DNA analysis in 1996, and of Bergson Gurjão Farias, located at Xambioá in 1996 and proved by DNA analysis in $2009 .{ }^{48}$ The frustration from the perspective of both scientists and relatives seems valid.

The gradual and unproductive progress of the transitional justice process - 
despite these apparent initiatives - follows a pattern that can be found in postconflict interventions in many jurisdictions, however.

\section{Truth commissions and forensic investigations}

In Truth Commissions and the Recognition of State Crime, Stanley ${ }^{49}$ observes that the role of the truth commission centres on the 'acknowledgement of identities (who people are and what they have experienced) alongside actions that permit individuals to redress the balance, enabling them to engage in peer social life (responding to what people need)'.$^{50}$

Stanley's contention is built on the work of Nancy Fraser ${ }^{51}$ and others. Fraser ${ }^{52}$ asserts that a commonplace assumption of recent decades, that justice must be served by recognising harms suffered by culturally disadvantaged groups, is insufficient: these simplify individual experience and force individuals to conform to categories of the socially marginalised - 'who people are has become more important than what people need'. ${ }^{33}$ Stanley argues that recognition is of particular significance to state crimes as these tend to be hidden or masked in the supposedly legitimate activities of the state, ${ }^{54}$ misrepresenting both victim and perpetrator. Groups claiming to represent victims of particular state crimes seek recognition of their victimhood - and truth commissions seek to acknowledge them as victims. ${ }^{55}$

The extent to which truth commissions also choose to recognise the identity of or involve perpetrators in their activities varies and may not occur at all. While engagement with perpetrators did occur in the work of the South African truth commission, for example, various mechanisms were apparently employed in 'damage limitation' to the reputation of various state and other actors involved in criminal activity. ${ }^{56}$ Many perpetrators did not attend the South African tribunal at all and others who did so appear to have shown disdain, certainly in the perception of victims' relatives. In addition, Stanley observes in Chile that victim advocacy groups have been marginalised from the reconciliation process, and in Indonesia the state has entirely exonerated all of its citizens of 'crimes against humanity' in Timor Leste. ${ }^{57}$

The second concern that arises from the work of both Fraser and Stanley is the response, specifically, to the needs of victims. Stanley ${ }^{58}$ is doubtful that the truth commissions of South Africa or Timor Leste attended to the needs of victims, be they for simple purposes - such as a gravestone - or substantial ones - such as a means of earning a living. Indeed, in Timor Leste at least, the truth commissioners appeared to reject the suggestion that such things were part of their mandate, implying they were in reality the responsibility of government. ${ }^{59}$

The specific role played by forensic science in the investigation of clandestine graves and human remains in transitional justice has been examined by Claire Moon $^{60}$ in Interpreters of the Dead: Forensic Knowledge, Human Remains and the Politics of the Past. Moon critiques the claims of forensic scientists - in particular, forensic archaeologists and anthropologists - in relation to humanitarian work, and it was the efforts commencing in the 1980s to - literally and metaphorically - unearth the atrocities of the Latin American dictatorships that allowed forensic 
anthropologists to gain international attention. Of particular prominence was the work of US forensic anthropologist Clyde Snow and his contribution to the development of the Equipo Argentino de Antropologia Forense or EAAF (Argentine Forensic Anthropology Team). The EAAF lent a substantial scientific contribution to the activities of the Comisión Nacional sobre la Desaparición de Personas or CONADEP (National Commission on the Disappeared) as well as the Asociación Madres de Plaza de Mayo (Association of the Mothers of the Plaza de Mayo) - a group consisting of mothers of the disappeared. ${ }^{61}$ In 1989 the United Nations adopted the Minnesota Protocol as a model for 'legal investigation of extra-legal, arbitrary and summary executions', ${ }^{62}$ integrating forensic investigation within a wider humanitarian legal structure. ${ }^{63}$ These events are seen as significant points in establishing the 'central significance of the dead' in the politics of the past and the 'emergence of forensic knowledge in the resignification of past atrocity'. ${ }^{64}$

Moon identifies key claims of forensic anthropology, which may be scientific, probative, humanitarian, historical, political and deterrent. To briefly summarise (and partly paraphrase) Moon: they are scientific in the sense that they claim to be based on objective analysis of empirical physical findings, they are probative in that they claim to offer legally admissible evidence that may lead to a conviction; they are humanitarian in that they claim to bring solace by determining the identity and fate of the deceased; they are historical in that they claim via scientific means to 'set the record straight'; they are political in that they claim to facilitate political and judicial reform; and they are deterrent in that they claim to demonstrate via current prosecutions that future offending will be found out and punished. Moon sees a statement attributed to the Peruvian forensic anthropologist now leading investigations of the Vala de Perus, Dom Bosco Cemetery, São Paulo as symbolic of the claims of forensic anthropology: 'we are interpreters of the dead' who 'will be able to say what these bodies reveal'. ${ }^{65}$

Moon, however, is sceptical with regard to the validity of both scientific and historical claims. She notes, in particular, the problems with the determination of 'race' ${ }^{66}$ Issues of interpretation affect many other aspects of the assessment of biographic parameters of the skeleton, although perhaps not quite to the same extent. ${ }^{67}$ Attribution of ancestry from the skeleton is a particular problem in Brazil, ${ }^{68}$ due to the country's history of extensive admixture and intermarriage, involving indigenous Brazilians and European, African, Middle-Eastern and, latterly, Japanese immigrants. In the context of the victims of the Araguaia guerrilla war, as would be the case in most regions of Brazil, remains of individuals of indigenous, Indo-European and African ancestry, and mixtures thereof, are encountered in investigations. Osteological methods developed in North America or Europe may not be applicable to Brazilian populations, however, and contemporary research in forensic anthropology in Brazil is intended to address specific methodological problems in the estimation of ancestry and other biographical parameters from skeletal remains in local populations. ${ }^{69}$ Moon also notes wider inadequacies of investigations, including that of CONADEP in Argentina, which has not achieved comprehensive identification of victims' remains and which is seen by some as having been subservient to the post-dictatorship government, 
rather than attending to the needs of relatives. ${ }^{70}$ The Madres, for example, did not want excavation and exhumation of remains to proceed without accompanying investigations that would identify and lead to the prosecution of the culprits. ${ }^{71}$ Transitional justice is not a simple scientific-legal process, as it is influenced by other social, legal and political forces: 'science does not provide an Archimedean point from which to settle such disputes' ${ }^{72}$

These observations differ from the kind of forensic authority discussed by Stefan Timmermans who, in Postmortem: How Medical Examiners Explain Suspicious Deaths, ${ }^{73}$ describes the medical examiner as a rational-legal authority typical of state bureaucracies as defined by Weber, ${ }^{74}$ further modified as scientific. The medical examiner's authority rests on 'voluntary compliance with decisions that run counter to personal, legal or political interests', on scientific methods that confer an 'aura of neutrality and objectivity, thereby reducing the potential for conflicts of interests' and, ultimately, the 'fulfilment of the cultural need to explain suspicious deaths for the public good' ${ }^{75}$

In Brazil, medical examiners of the dictatorship era seem to have been complicit in the concealment of torture and killing, and the servants of personal interests or political pressures. In contemporary democratic Brazil, the aura of forensic science is utilised by policy makers and frequently discussed in the media. Some Brazilian experts, however, are questioning the methodologies of government-appointed experts from inside and outside of the country, and the motives of government in making and offering justification for such policies: as Stover and Ryan ${ }^{76}$ observe, the forensic expert needs to understand the legal and evidentiary procedure of the jurisdiction and, especially salient in this context, its political and cultural dynamics. Even forensic genetics, which has proved to be central to human identification in Bosnia-Herzegovina and is a powerful tool in humanitarian investigation, still needs to be implemented with reference to the needs and expectations of relatives. ${ }^{77}$

How should the transitional justice process in Brazil be regarded in the context of these observations?

\section{Implications for the transitional justice process in Brazil}

The Commisão Nacional da Verdade, established in 2011, had only a short mandate, which was extended to the end of 2014. It has been criticised from a number of perspectives, including poor planning and organisation, lack of communication and transparency, and the absence of a reparative dimension - and, ultimately, its 'democratic deficit'. ${ }^{78}$ Former government ministers have also expressed concern about the failure to bring perpetrators to justice. Central to this problem is the contentious issue of the 1979 Amnesty Law and its contemporary validity and applicability. ${ }^{79}$ As ex-human rights minister Paulo Vannuchi argues, this ambivalence leaves Brazil stuck between past and present ${ }^{80}$ - and the Amnesty Law, he argues, does not apply to torturers; ${ }^{81}$ a view echoed by the Commisão Nacional da Verdade in its final report, which regards such crimes as 'imprescritíveis e não passíveis de anistia' (imprescriptible and not susceptible to amnesty). ${ }^{82}$ 
That the ruling of the Inter-American Commission on Human Rights is still contested in Brazil - including by the solely dissenting member of the Commisão Nacional da Verdade - may be symptomatic of the transition in Brazil, discussed by Scott Mainwaring. Democratisation in Brazil, as in other Latin American countries, began as a process of 'liberalization from above'. While Brazil moved quite rapidly to a consolidation phase, it is still a new democracy and the 'battles to define the rules' are on-going. ${ }^{83}$ Furthermore, the point made by Mainwaring in 1989 remains prescient:

One of the most encouraging steps of the new democracy is that it has respected traditional civil liberties $[\ldots]$ the high level of continuity during the transition means that the right is engaged in, rather than outside of, democratic politics; this is a fact that might augur well for the stability of the new regime. But significant changes in Brazil's profoundly elitist political culture, or significant measures to address the egregious poverty that afflicts tens of millions of people in what has become one of the Third World's richest economies, still have not appeared on the horizon. ${ }^{84}$

Brazil is now the world's seventh-largest economy by GDP,${ }^{85}$ but Brazilian politicians continue to struggle with both human rights and socio-economic challenges.

In October 2014 the Inter-American Court of Human Rights of the Organisation of American States resolved that the Brazilian government had still not complied with its ruling to conduct an appropriate criminal investigation of the facts relating to the Araguaia War, punish the perpetrators of the violations and apply the penalties provided by law. The Court also resolved that the Amnesty Law, which guarantees immunity to offenders even though their crimes are imprescriptible, in particular continues to interfere with the criminal liability of officials who committed abuses in a manner that is incompatible with the American Convention on Human Rights. ${ }^{86}$

These rulings illustrate the complex factors affecting forensic science and medicine in post-dictatorship Brazil, and the political and administrative processes affecting the investigation of the alleged human rights abuses of the military government. Investigations were initially led by the Special Commission for the Political Dead and Disappeared and the National Secretary for Human Rights. Initially part of the Ministry of Justice, the Human Rights Secretary was later elevated to Ministry status ${ }^{87}$ and the Special Commission was incorporated within its structure. ${ }^{88}$ In 2010 , the Secretariat was elevated to become part of the President's Office and its name was amended to the Secretary of Human Rights of the President of the Republic (Secretaria de Direitos Humanos da Presidência da República or SDH/PR). ${ }^{89}$

Despite commitments to transitional justice by the Brazilian government, the GTA commenced its activities only following the intervention of the InterAmerican Commission, and even then in the face of continued resistance from the government based on the Amnesty Act of 1979. Similar strategies in other Latin American countries have failed: Brazil is the only Latin American country not to have invalidated such laws - a situation seen as an international scandal that may 
preclude a Brazilian seat on the United Nations Security Council. ${ }^{90}$ In a further judgment, the Inter-American Court of Human Rights ruled against the Amnesty Law, concluding that 'no law or rule of law, such as provisions of an amnesty [...] should prevent the State from meeting its inalienable obligation to punish crimes against humanity'. ${ }^{91}$ Brazil has yet to comply with this obligation.

The final report ${ }^{92}$ of the Commisão Nacional da Verdade made twenty-nine recommendations to the Brazilian State, among which was item 27:

Continuation of the activities aimed at locating, identifying and delivering to the families or legitimate persons the remains of the victims of political disappearances, so they may be buried with dignity.

As recently as October 2015, Sebastião Rodrigues de Moura, known as 'Major Curió', a former soldier accused of ordering and leading human rights violations during the Araguaia War, confessed before the 1st Federal Court in Brasília - the Court responsible for the Araguaia investigations - to the killings of two guerrillas, Antônio Theodoro Castro and Cilon Cunha Brun, and to burying their bodies in an area already known to relatives of the victims following information from local people. ${ }^{93}$ In the absence of forensic evidence, it is an open question whether Curió's claim that the prisoners were shot while trying to escape is truthful or disdainful. What is known, however, is that the GTA had not considered this location important, leading to disappointment and indignation amongst families and, while Aronson ${ }^{94}$ notes the potentially contentious nature of prioritisation of searches, this case in Araguaia arises from a conflict between the views of public servants and victims' relatives, rather than a difference of views between relatives themselves. This apparent oversight on behalf of the coordinators of the GTA investigations is in marked contrast to the meticulousness with which its field excavations are conducted and recorded. Attempts to shift responsibility away from the state and onto victims and perpetrators in a process described by Jamieson and MacEvoy ${ }^{95}$ as 'juridical othering' does not seem particularly evident in Brazil, but dissenting relatives and some scientists may experience passive exclusion of the kind that has led them to withdraw from the Araguaia and Perus investigations. Furthermore, the same Federal Court ordered that the Ministério Público Federal (MPF) must investigate the GTA's finances, given that it completed three years of activities without producing effective results. ${ }^{96}$ This, and the already lengthy list of concerns given above, give the appearance of a damage-limitation exercise serving the aims of government.

With regard to the needs of relatives, Eppel's ${ }^{97}$ account of investigations of mass graves in Matabeleland, Zimbabwe indicates that families generally regarded the process there as positive, 'healing rifts' and 'putting right wrongs'. The Brazilian situation, however, remains closer to the 'pact of silence' resulting from an Amnesty Law discussed by Renshaw ${ }^{98}$ in relation to the Spanish Civil War. Renshaw notes the importance of the recent investigations in Spain - a process initiated by relatives of victims, as it was in Araguaia - of establishing a new 'memory' or account of events free from the domination consequent on Franco's victory in the war. 
In Brazil, in the absence of effective investigations, this process cannot progress beyond recollection and impasse. For example, the Commisão Nacional da Verdade has heard evidence from witnesses ${ }^{99}$ who are relatives of the disappeared and who also represent other family members, some of whom are now in old age, as well as the children of victims. These families are searching for the remains of fathers, mothers, husbands, brothers and sisters. One witness describes her brother: 'Well, he was a studious boy who had a political conscience that's hard to find today, despising no one - for the love of God.' She describes the family resemblance of a child where the lack of opportunity for a conclusive DNA test - which would be greatly facilitated if the father's remains could be found - is preventing the genetic confirmation of the family relationship: 'she looks a lot like my sister, a lot, and if you look at her you wonder how they both can look so much alike'. Another witness describes the consequences of the loss of a father for his son: 'Look ... physical effects, malnutrition, my son appears like in Africa these days, a land of hunger; he seems like those children in Africa ...' She goes on to say: 'my son hates anything to do with the government, from school, everything ... but people live in this State ...'.

According to lawyer Rafael Custódio, ${ }^{100}$ who commented on these hearings, 'members of the commission had the opportunity to compare the concerns of civil society with the justifications of the State for the lack of concrete progress', but it is difficult to see how these can be reconciled. While relatives may be acknowledged as victims, lack of results in investigations prevents progress for families and causes impediments to participation in social life - as referred to by Stanley - that are passed on to future generations. The deceased are not identified, and the location and excavation of victims' remains cannot provide a site for 'grieving and commemoration'. ${ }^{101}$ They have 'no gravestone' and no human remains about which it would be possible to say 'who they are' and 'what they have experienced'.

To follow Fraser, victims' relatives may see themselves as part of a disadvantaged and unrecognised group - perhaps part of a political movement descended from the resistance against the military government - but this is neither universal nor implicit. Others may view their disappeared relatives to have been the victims both of the state and of the cynical self-interest of other actors who drew power from their opposition to it. ${ }^{102}$

The Grupo Independente dos Familiares dos Mortos e Desaparecidos Políticos (Independent Group of Families of the Political Dead and Disappeared) consists of individuals who share a need to see their relatives' remains identified and their fate revealed. Representatives of the group are active in support of investigations and frequently attend searches and excavations, and produce commentaries on these. ${ }^{103}$ The lack of progress in government-led projects is a cause of frustration to many family members and the involvement of state agencies - some of which participated in the repression - is a source of concern to them and to local people who find the investigations a source of further insecurity. In Araguaia the twentyseven skeletons recovered since 2011 have been placed in storage: no attempt at identification has been made. Frustration with progress has led some relatives of the disappeared to conduct investigations privately (personal communica- 
tions of representatives of the Grupo Independente dos Familiares dos Mortos e Desaparecidos Políticos, 2015). This process of family-led investigation was also evident among the Madres of Argentina. In Mexico, another jurisdiction where state intervention in the identification of victims of civil conflict is limited - despite the enormous number of victims - Moon ${ }^{104}$ has noted the establishment of a 'citizen forensics organisation' where relatives of the disappeared have collaborated to establish their own DNA reference database.

Salient to this issue are the observations of Rosenblatt ${ }^{105}$ regarding the contention between the forensic scientist's professional work and potential role as an activist. In Perus, it has so far proved difficult for the forensic anthropologist to be the 'interpreter of the dead' and say 'what these bodies reveal'. Instead, the investigation is reinterpreted as a 'pretext' to understand how a country like Brazil can end up with 'more than a thousand bodies having no identity'. ${ }^{106}$

While forensic scientists may hope to combine a commitment to dispassionate objectivity with a desire to deliver processes and findings that will offer some consolation to relatives, as discussed by Timmermans, activism is clearly problematic in the context of criminal investigation. In Brazil, however, it is not a question of finding evidence that may or may not support a particular version of events, but of finding any substantial evidence regarding the identification and fate of victims.

\section{Conclusions}

In the face of wilful attempts to conceal the crimes of the military dictatorship and the remains of victims, it might be anticipated that the democratic governments of Brazil that have arisen in the thirty years since 1985 will have taken steps to identify victims and determine their fate, and to restore their remains to their relatives. The ultimate aims of transitional justice are to offer restitutions to victims by acknowledging their identities and experiences, addressing their needs and allowing them an equitable return to society. In apparent support of this agenda, the government of Brazil has introduced legislation, established offices and commissions and conducted a series of forensic investigations, like those in Araguaia and Perus, São Paulo.

The reality in Brazil, however, follows the pattern of a number of other jurisdictions, such as Argentina, South Africa and Timor Leste. It is occurring in an environment in which there are a variety of sectional interests competing for influence. The use of a 1979 Amnesty Law to impede investigation and prosecution is particularly controversial, due to its questionable legality and applicability under international human rights laws and conventions to which Brazil is a signatory.

The Commisão Nacional da Verdade and other state agencies have done something to reveal the complexity of state crime and to recognise victims and their living relatives, but are still far from a full acknowledgement of victims' and perpetrators' identities and victims' fates. Most noticeably, a large number of skeletal remains have yet to be identified, and identification of victims and their fates is widely acknowledged as the first step in the transitional justice process. Without it, the experiences of the disappeared cannot be revealed and fundamental needs 
of living relatives cannot be met. It is also of critical importance in the detection and prevention of crime. Given the relatively small number of victims concerned, many of whom are named, the lack of progress is as difficult to comprehend scientifically as it is administratively. For some forensic scientists and relatives of the disappeared, the official transitional justice process is seen as disingenuous and not trustworthy.

The search for bodies is regarded as an unreliable process by families, many of whom still put their hopes in searches for the remains and are prepared to conduct their own investigations, as occurred before the government became involved. Some Brazilian forensic scientists are sceptical of the sincerity of the government and question its scientific policy. Relatives remain suspicious of any involvement in investigation by agencies - like the civic medico-legal institutes - that once colluded in the concealment of torture and killing. For local populations, investigations are perceived as a source of problems and a cause of fear.

\section{Notes}

1 E. Stanley, 'Evaluating the Truth and Reconciliation Commission', Journal of Modern African Studies, 39:3 (2001), 525-46; E. Stanley, 'Truth Commissions and the Recognition of State Crime', British Journal of Criminology, 45 (2005), 582-97.

2 C. Moon, 'Interpreters of the Dead: Forensic Knowledge, Human Remains and the Politics of the Past', Social and Legal Studies, 22:2 (2012), 149-69.

3 C. N. Toledo, ' 1964 O golpe contra as reformas e a democracia', Revista Brasileira História, 24:47 (2004), 13-28; M. B. Mattos, 'O governo João Goulart: novos rumos da produção historiográfica', Revista Brasileira História, 28:55 (2008), 245-63; M. Soriano Neto, 'A Revolução de 31 de março de 1964 - Uma análise sumária de suas causas’, Revista do Clube da Aeronáutica, 260 (2013), 18-21;

C. Castro, O golpe de 1964 e a instauração do regime militar, Centro de Pesquisa e (São Paulo, Documentação de História Contemporânea do Brasil-Fundação Getúlio Vargas (FGV-CPDOC), 2012), http://cpdoc.fgv.br/producao/dossies/ FatosImagens/Golpe1964 (accessed 30 March 2017).

4 W. Lima, 'Brasil foi o único país da América Latina a mascarar golpe com "ar democrático"', Último Segundo, 28 March 2014, http://ultimosegundo.ig.com. br/politica/2014-03-28/brasil-foi-o-unico-pais-da-america-latina-a-mascarargolpe-com-ar-democratico.html (accessed 30 March 2017).

5 Castro, O golpe de 1964 e a instauração do regime militar; D. A. Reis, Ditadura e democracia no Brasil (Rio de Janeiro, Zahar, 2014).

6 Direito à Memória e à Verdade: Comissão Especial sobre Mortos e Desaparecidos Políticos (Brasilia, Secretaria Especial dos Direitos Humanos da Presidência da República, 2007), www.sdh.gov.br/assuntos/mortos-e-desaparecidos-politicos/ pdfs/livro-direito-a-memoria-e-a-verdade (accessed 30 March 2017).

7 C. Marighella, Manual do guerrilheiro urbano (1969), www. documentosrevelados.com.br/wp-content/uploads/2015/08/carlos-marighellamanual-do-guerrilheiro-urbano.pdf (accessed 30 March 2017). 
8 R. P. Campos Filho, Guerrilha do Araguaía: A esquerda em armas (São Paulo, Anita Garibaldi Fundação Maurício Grabois, 2012).

9 A. Monteiro, Guerrilha do Araguaía: Uma Epopéia pela Liberdade (São Paulo, Anita Garibaldi, 2005).

$10 \mathrm{H}$. Studart, A lei da selva: Estratégias, imaginário e discurso dos militares sobre a Guerrilha do Araguaía (São Paulo, Geração Editoria, 2006).

11 L. Nossa, Mata! O Major Curió e as Guerrilhas no Araguaía (São Paulo, Companhia das Letras, 2012).

12 Direito à Memória e à Verdade: Comissão Especial sobre Mortos e Desaparecidos Políticos.

13 Projeto Marcas da Memória, Vala Clandestina de Perus: Desaparecidos Políticos, um capítulo não encerrado da História Brasileira edição de texto Instítuto Macuco (São Paulo, do Autor, 2012), www.dhnet.org.br/verdade/rn/bibliografia/ livro_vala_perus_emmanuel.pdf (accessed 30 March 2017).

14 Campos Filho, Guerrilha do Araguaía: A esquerda em armas.

15 A. Monteiro, Guerrilha do Araguaía: Uma Epopéia pela Liberdade.

16 T. Morais and E. Silva, Operação Araguaía: os arquivos secretos da guerrilha (São Paulo, Geração Editorial, 2005).

17 Projeto Marcas da Memória, Vala Clandestina de Perus: Desaparecidos Políticos, um capítulo não encerrado da História Brasileira.

18 Ibid.

19 M. A. Guimarães, R. A. Francisco, R. de Abreu e Souza and M. P. Evison, 'Forensic Archaeology and Anthropology in Brazil', in M. Groen, N. MárquezGrant and R. Janaway (eds), Forensic Archaeology: A Global Perspective (Chichester, Wiley, 2015), 215-22.

20 República Federativa do Brasil, Lei no 6.683, de 28 de Agosto de 1979, Anistia (1979), www.planalto.gov.br/ccivil_03/leis/L6683.htm (accessed 30 March 2017); República Federativa do Brasil, Lei no 10.559, de 13 de Novembro de 2002, Regulamenta o art. 80 do Ato das Disposições Constitucionais Transitórias e dá Outras Providências (2002), www.planalto.gov.br/ccivil_03/leis/2002/L10559. htm\#art22 (accessed 30 March 2017).

21 República Federativa do Brasil, Constituição da República Federativa do Brasil de 1988 (1988), www.planalto.gov.br/ccivil_03/constituicao/constituicao.htm (accessed 30 March 2017).

22 República Federativa do Brasil, Lei no 9.140, de 04 de Dezembro de 1995, Reconhece Como Mortas Pessoas Desaparecidas em Razão de Participação, ou Acusação de Participação, em Atividades Políticas, no Período de 2 de Setembro de 1961 a 15 de Agosto de 1979 (1995), www.planalto.gov.br/ccivil_03/leis/L9140. htm (accessed 30 March 2017).

23 República Federativa do Brasil, Decreto no 2.193, de 7 de abril de 1997, Aprova a Estrutura Regimental do Ministério da Justiça (1997), www.planalto.gov.br/ ccivil_03/decreto/D2193.htm (accessed 30 March 2017).

24 República Federativa do Brasil, Lei no 12.528, de 18 de Novembro de 2011, Cria a Comissão Nacional da Verdade (2011), www.planalto.gov.br/ccivil_03/_ Ato2011-2014/2011/Lei/L12528.htm (accessed 30 March 2017). 
25 Inter-American Commission on Human Rights, Araguaía Guerrilla Movement, Brazil, Report No 33/01, Case 11.552, 6 March 2001, section 34, http://cidh.org/ annualrep/2000eng/ChapterIII/Admissible/Brazil11.552.htm (accessed 30 March 2017).

26 Ibid., section 59.

27 Inter-American Commission on Human Rights of the Organization of American States, American Convention on Human Rights (1969), www.cidh.oas.org/ basicos/english/basic3.american\%20convention.htm (accessed 30 March 2017).

28 Organization of American States, American Declaration of the Rights and Duties of Man (1948), wwwl.umn.edu/humanrts/oasinstr/zoas2dec.htm (accessed 30 March 2017).

29 República Federativa do Brasil, Portaria No 567/MD, de 29 de Abril de 2009, Criação do Grupo de Trabalho Para localização, Recolhimento e Identificação de Mortos da Guerrilha do Araguaía 2009), http://pfdc.pgr.mpf.mp.br/atuacaoe-conteudos-de-apoio/legislacao/direito-a-memoria-e-a-verdade/portarias/ portaria\%20567.pdf (accessed 30 March 2017).

30 Relatório do Grupo de Trabalho Araguaía, 2a Expedição - 8 a 18 de Julho de 2012 (Brasilia, Secretaria de Direitos Humanos: Grupo de Trabalho Araguaía, 20 June 2012); Relatório do Grupo de Trabalho Araguaía, 5 a Expedição - 14 a 26 de Outubro de 2012 (Brasilia, Secretaria de Direitos Humanos: Grupo de Trabalho Araguaía, 24 October 2012); Relatório do Grupo de Trabalho Araguaía, 2a Expedição - 16 a 27 de Outubro de 2013 (Brasilia, Secretaria de Direitos Humanos: Grupo de Trabalho Araguaía, 26 October 2013).

31 'Family Receives New Death Certificate of Journalist Killed during Brazilian Dictatorship', Folha de São Paulo, 16 March 2013, www1.folha.uol.com.br/ internacional/en/brazil/2013/03/1247557-family-receives-new-death-certificateof-journalist-killed-during-brazilian-dictatorship.shtml (accessed 30 March 2017).

32 R. Francisco, A. P. Garieri, A. R. Meinicke, M. Talhavini, M. Jost, J. M. Freitas et al., 'Evidence of the Institutional Concealment of Torture and Homicide during the Brazilian Military Government of 1964-85', (submitted to Science \& Justice 2016).

33 Projeto Marcas da Memória, Vala Clandestina de Perus: Desaparecidos Políticos, um capítulo não encerrado da História Brasileira.

34 F. Amorim, 'Peritos da USP abandonam trabalho de identificação de ossadas', Folha de São Paulo, 26 February 2014, www1.folha.uol.com.br/ poder/2014/02/1418085-peritos-da-usp-abandonam-trabalho-de-identificacaode-ossadas.shtml (accessed 30 March 2017).

35 T. Farah, 'Governo contrata peritos e reabre o caso das "ossadas de Perus": Primeira etapa do trabalho terá orçamento de $\mathrm{R} \$ 2,4$ milhões', http://oglobo. globo.com/brasil/governo-contrata-peritos-reabre-caso-das-ossadas-deperus-12490446 (accessed 30 March 2017).

36 Guimarães, et al., 'Forensic Archaeology and Anthropology in Brazil'.

37 D. Adam, 'Brazilian Forensic Medicine: Back from the Dead', Nature, 423 (2003), 13-14; M. A. Guimarães, 'The Challenge of Identifying Deceased Individuals 
in Brazil: from Dictatorship to DNA Analysis', Science and Justice, 43:4 (2003), 215-17.

38 FCO, Science and Innovation Annual Report 2004-2005 (London, Foreign and Commonwealth Office, 2005), 74.

39 A. T. C. Soares and M. A. Guimarães, 'Two Years of Forensic Anthropology at the Medico Legal Centre (CEMEL) of the Faculty of Medicine of Ribeirão Preto-USP', Medicina (Ribeirao Preto), 41:1 (2008), 7-11; R. A Francisco, A. P. S Velloso, T. C. P Silveira, J. M. Secchieri and M. A. Guimarães, 'Forensic Anthropology at Medico Legal Centre of the Faculty of Medicine of Ribeirão Preto/USP - Comparative Study of Cases from 1999-2009', Medicina (Ribeirão Preto), 44:3 (2011), 241-8; R. A. Francisco, R. H. A. Silva, J. M. Pereira, E. G. Soares, E. Matheucci Júnior, E. S. M. Iwamura and M. A. Guimarães, 'Forensic Anthropology Screening for Analyses of Forensic Genetics', Saúde, Ética \& Justiça, 18:1 (2013), 128-33.

40 M. P. Evison, R. A. Francisco and M. A. Guimarães, 'Approaching Utility in Forensic Anthropology', Forensic Science Policy \& Management: An International Journal, 3:2 (2012), 85-104; M. P. Evison, R. A. Francisco and M. A. Guimarães, 'Utility in Forensic Anthropology: Findings Contributing to Case Conversion', Forensic Science Policy \& Management: An International Journal, 3:2 (2012), 113-25.

41 M. A. Guimarães, R. A. Francisco, C. E. P. Machado, R. H. A. Silva, E. S. M. Iwamura and M. P. Evison, 'Forensic, Scientific and Political Aspects of Exhumations in Brazil: An Academic Perspective', Human Remains and Violence: An Interdisciplinary Journal, 3:1 (2017) 37-51, www.ingentaconnect. $\mathrm{com} / \mathrm{content} / \mathrm{manup} / \mathrm{hrv} / 2017 / 00000003 / 00000001 /$ art00004;jsessionid=6nqjuo4 7n6qkf.x-ic-live-02.

42 Farah, 'Governo contrata peritos e reabre o caso das "ossadas de Perus"; Unifesp cria primeiro Centro de Antropologia e Arqueologia Forense do Brasil, UNIFESP, 5 August 2014, http://www.unifesp.br/boletins-anteriores/item/1369-2714 (accessed 30 March 2017); 'Violência de Estado e Direitos Humanos no Brasil', FCL, 4 April 2016, www.britishcouncil.org.br/events/violencia-de-estadodireitos-humanos-no-brasil (accessed 30 March 2017).

43 T. Barreto, 'Peritos estrangeiros ajudarão a identificar ossadas da Vala de Perus', Carta Capital, 24 January 2014, www.cartacapital.com.br/politica/peritos-doperu-e-da-argentina-ajudam-a-identificar-ossadas-de-perus-3195.html (accessed 30 March 2017); B. Bocchini, 'Grupo de trabalho identifica primeiras ossadas da vala de Perus', Rede Brasil Atual, 13 December 2014, www.redebrasilatual.com. br/cidadania/2014/12/grupo-de-trabalho-identifica-primeiras-ossadas-da-valade-perus-416.html (accessed 30 March 2017); 'Ossadas de vala clandestina em SP começam a ser identificadas', O Globo Fantástico, 26 June 2016, http://g1.globo. com/sao-paulo/noticia/2014/04/analise-das-ossadas-de-perus-sera-coordenadapor-equipe-da-unifesp.html (accessed 30 March 2017).

44 'Ossadas de Perus ainda esperam identificação', Jornal de Gazeta, 10 November 2016, www.tvgazeta.com.br/videos/ossadas-de-perus-ainda-esperamidentificacao/ (accessed 30 March 2017). 
45 Amorim, 'Peritos da USP abandonam trabalho de identificação de ossadas'; 'Cemel de Ribeirão deixa programa para investigar ossadas no cemitério de Perus', O Globo, Ribeirão e Franca, undated, http://g1.globo.com/sp/ribeiraopreto-franca/jornal-da-eptv-2edicao//videos/v/cemel-de-ribeirao-deixaprograma-para-investigar-ossadas-no-cemiterio-de-perus/3364332/ (accessed 30 March 2017).

46 'Assista: “Ossadas da Vala Clandestina de Perus, de 1970 a 2015”', GGN, 2 February 2017, http://jornalggn.com.br/noticia/assista-\%E2\%80\%9Cossadasda-vala-clandestina-de-perus-de-1970-a-2015\%E2\%80\%9D (accessed $30 \mathrm{March}$ 2017).

47 Comissão Nacional da Verdade, Relatório da Comissão Nacional da Verdade (Brasilia, Comissão Nacional da Verdade, 2014), www.cnv.gov.br/index. php?option=com_content\&view=article\&id $=571($ accessed 30 March 2017), conclusion 5.

48 'Novo teste de DNA confirma que ossada encontrada no Araguaía era de guerrilheiro', UOL Noticias, 7 July 2009, http://noticias.uol.com.br/ cotidiano/2009/07/07/ult5772u4596.jhtm (accessed 30 March 2017).

49 Stanley, 'Truth Commissions and the Recognition of State Crime'.

50 Ibid., p. 586.

51 N. Fraser, Justice Interruptus: Critical Reflections on the Postsocialist Condition (London, Routledge, 1997); N. Fraser, 'Rethinking Recognition', New Left Review, 3 (2000), 107-20. N. Fraser, Social Justice in the Age of Identity Politics: Redistribution, Recognition and Participation, WZB Discussion Paper, No. FS I 98-108 (Berlin, WZB Berlin Social Science Center, 1998).

52 Fraser, Justice Interruptus.

53 Stanley, 'Truth Commissions and the Recognition of State Crime', p. 584.

54 Ibid., p. 554.

55 Ibid., pp. 554-5.

56 Ibid.

57 Ibid., p. 591.

58 Ibid., pp. 592-3.

59 Ibid., p. 593.

60 C. Moon, 'Interpreters of the Dead'.

61 Ibid.

62 United Nations Centre for Social Development and Humanitarian Affairs, Manual on the Effective Prevention and Investigation of Extra-Legal, Arbitrary and Summary Executions, ST/CSDHA/12 (Vienna, United Nations Centre for Social Development and Humanitarian Affairs, 1991), www.ohchr.org/ Documents/Issues/Executions/UNManual2015/Annex1_The_UN_Manual.pdf (accessed 30 March 2017).

63 Moon, 'Interpreters of the Dead', p. 152.

64 Ibid., p. 150.

65 Ibid., pp. 157-9.

66 Ibid., pp. 162-3.

67 M. P. Evison, 'Forensic Anthropology and Human Identification from the 
Skeleton', in J. Fraser and R. Williams (eds), Handbook of Forensic Science (London, Willan, 2009), 84-112.

68 Guimarães et al., 'Forensic Archaeology and Anthropology in Brazil'.

69 R. A. Francisco, M. P. Evison, M. L. da C. Junior, T. C. P. Silveira, J. M. Secchieri and M. A. Guimarães, 'Validation of a Standardized Forensic Anthropology Examination Protocol in a Novel Population by Measurement of Applicability and Reliability in Contemporary Samples of Known Attribution' (submitted to Forensic Science International 2017).

70 Moon, 'Interpreters of the Dead:', p. 164.

71 Ibid., p. 165.

72 Ibid., p. 166.

73 S. Timmermans, Postmortem: How Medical Examiners Explain Suspicious Deaths, Chicago, University of Chicago Press, 2006).

74 M. Weber, Economy and Society: An Outline of Interpretive Sociology, edited by G. Roth and C. Wittich (Los Angeles, University of California Press, 1978), 263.

75 Timmermans, Postmortem, p. 252.

76 E. Stover and M. Ryan, 'Breaking Bread with the Dead', Historical Archaeology, $35: 1$ (2001), 7-25.

77 E. Stover and R. Shigekane, 'The Missing in the Aftermath of War: When Do the Needs of Victims' Families and International War Crimes Tribunals Clash?', International Review of the Red Cross, 848 (2002), 845-66.

78 C. J. Schallenmeuller, Transitional Justice in Brazil and Uruguay: Different Solutions to the Tension between Human Rights and Democracy, Glasgow, European Consortium for Political Research General Conference 2014, http:// ecpr.eu/Filestore/PaperProposal/d2fd5e71-e28d-4c21-9710-bd76d2df4f2d.pdf (accessed 30 March 2017), 10-11.

79 Ibid., pp. 20-1.

80 'Ex-ministro defende punição contra violações da ditadura', Estadão de São Paulo, 24 July 2011, http://politica.estadao.com.br/noticias/geral,ex-ministrodefende-punicao-contra-violacoes-da-ditadura,749291 (accessed 30 March 2017).

81 'Ex-ministro Paulo Vannuchi é eleito para Comissão Interamericana de Direitos Humanos da OEA', Sindicato dos Advogados do Estado de São Paulo (2013), www.sasp.org.br/convenios/386-ex-ministro-paulo-vannuchi-e-eleito-paracomissao-interamericana-de-direitos-humanos-da-oea.html (accessed 30 March 2017).

82 Comissão Nacional da Verdade, Relatório da Comissão Nacional da Verdade (Brasilia, Comissão Nacional da Verdade, 2014), www.cnv.gov.br/index. php?option=com_content\&view=article\&id=571 (accessed 30 March 2016), conclusion 13.

83 S. Mainwaring, 'The Transition to Democracy in Brazil', Working Paper \#66 (Notre Dame, IN, The Helen Kellogg Institute for International Studies, 1986).

84 S. Mainwaring, 'Transitions to Democracy and Democratic Consolidation: Theoretical and Comparative Issues', Working Paper \#130. (Notre Dame, IN, The Helen Kellogg Institute for International Studies, 1989). 
85 World Bank Group, Gross Domestic Product 2014 (2015), http://data.worldbank. org/data-catalog/GDP-ranking-table (accessed 30 March 2017).

86 R. Custódio, 'Comissão Nacional da Verdade na OEA', Conectas Direitos Humanos, 23 March 2015, www.conectas.org/pt/acoes/justica/noticia/30829comissao-nacional-da-verdade-na-oea (accessed 30 March 2017).

87 República Federativa do Brasil, Lei no 10.683, de 28 de maio de 2003, Dispõe Sobre a Organização da Presidência da República e dos Ministérios, e dá Outras Providências (2003), www.planalto.gov.br/ccivil_03/leis/2003/110.683.htm (accessed 30 March 2017).

88 República Federativa do Brasil, Lei no 10.875, de 1 o de junho de 2004, Reconhece Como Mortas Pessoas Desaparecidas em Razão de Participação, ou Acusação de Participação, em Atividades Políticas (2004), www.planalto.gov.br/ccivil_03/_ ato2004-2006/2004/lei/110.875.htm (accessed 30 March 2017).

89 República Federativa do Brasil, Lei no 12.314, de 19 de Agosto de 2010, Dispõe Sobre a Organização da Presidência da República e dos Ministérios (2010), www.planalto.gov.br/ccivil_03/_ato2007-2010/2010/lei/l12314.htm (accessed 30 March 2017).

90 'Autor da contestação à Anistia afirma que decisão do STF acaba com chance brasiliera na ONU’, ZH Notícias, 30 April 2010, http://zh.clicrbs.com.br/rs/ noticias/noticia/2010/04/autor-da-contestacao-a-anistia-afirma-que-decisaodo-stf-acaba-com-chance-brasileira-na-onu-2890238.html (accessed 30 March 2017).

91 Inter-American Court of Human Rights, Gomes Lund et al. ('Guerrilha do Araguaía') v. Brazil, Judgment, 24 November 2010, www.corteidh.or.cr/docs/ casos/articulos/seriec_219_ing.pdf (accessed 30 March 2017).

92 R. Custódio, 'Relatório final da Comissão Nacional da Verdade: E agora, Brasil?', Conectas Direitos Humanos, 23 April 2015, www.conectas.org/pt/acoes/justica/ noticia/34863-relatorio-final-da-comissao-nacional-da-verdade-e-agora-brasil (accessed 30 March 2017).

93 L. Mazzini, 'Major Curió confessa à Justiça que matou prisioneiros no Araguaía', UOL Notícias Política, 15 October 2015, http://colunaesplanada.blogosfera.uol. com.br/2015/10/15/major-curio-confessa-a-justica-que-matou-prisioneiros-noAraguaía/ (accessed 30 March 2017).

94 J. Aronson, 'The Strengths and Limitations of South Africa's Search for Apartheid-era Missing Persons', The International Journal of Transitional Justice, 5:2 (2011), 262-81.

95 R. Jamieson and K. McEvoy, 'State Crime by Proxy and Juridical Othering', British Journal of Criminology, 45 (2005), 504-27.

96 Mazzini, 'Major Curió confessa à Justiça que matou prisioneiros no Araguaía'.

97 S. Eppel, "Bones in the forest” in Matabeleland, Zimbabwe: Exhumations as a Tool for Transformation', International Journal of Transitional Justice, 8:3 (2014), 404-25.

98 L. Renshaw, Exhuming Loss: Memory, Materiality and Mass Graves of the Spanish Civil War (Walnut Creek, CA, Left Coast Press, 2011).

99 'Testemunhos de Criméia Schmidt de Almeida, Danilo Carneiro, Maria Eliane de 
Castro e Elizabeth Silveira e Silva', Veja o Relatório Final da Commisão Nacional da Verdade, Brasilia, 31 August 2015, www.cnv.gov.br/todos-volume-1/658documentos-sobre-a-guerrilha-do-araguaia.html (accessed 30 March 2015); 'Audiência pública "Mortos e desaparecidos na guerrilha do Araguaia", Veja o Relatório Final da Commisão Nacional da Verdade, Brasilia, 31 August 2015 (Video), www.cnv.gov.br/todos-volume-1/658-documentos-sobre-a-guerrilhado-araguaia.html (accessed 30 March 2015).

100 Custódio, 'Relatório final da Comissão Nacional da Verdade'.

101 Z. Crossland, 'The Archaeology of Contemporary Conflict', in T. Insoll (ed.), The Oxford Handbook of the Archaeology of Ritual and Religion (Oxford, Oxford University Press, 2011), pp. 285-306.

102 José Genoíno, one of few guerrillas who survived the Araguaia War, ultimately gained office as a Partido dos Trabalhadores (Workers Party) Federal Deputy for São Paulo in the Brazilian Parliament. He has been associated with a guerrilla patrol in Araguaía which was subsequently implicated in the torture and murder of a local youth, João Pereira (See Discursos e Notas Taquigráficas, Câmara dos Deputados - DETAQ, 24 June 2005, http://goo.gl/roLKCh (accessed 30 March 2017)). In 2013, Genoino was found guilty of involvement in a major financial fraud the 'mensalão' scandal (see 'Brazil Mensalao trial: Former chief of staff jailed', BBC News, 16 November 2013, www.bbc.co.uk/news/world-latinamerica-24967116 (accessed 30 March 2017)).

103 See, for example, M. Castro and J. C. de Oliveira, 'Relatório de Maria Merces Castro e Jadiel C. de Oliveira', Grupo de Trabalho Araguaía - Expedição de Julho de 2011 (Brasilia, Ministério Público Federal, 2011), www.mpf.mp.br/atuacaotematica/ccr2/coordenacao/comissoes-e-grupos-de-trabalho/justica-transicao/ relatorios-1/1a-expedicao/ANEXO-1A.PDF (accessed 30 March 2017).

104 C. Moon, 'Human Rights, Human Remains: Forensic Humanitarianism and the Human Rights of the Dead', International Social Science Journal, 65:215-16, 46-63.

105 A. Rosenblatt, Digging for the Disappeared: Forensic Science after Atrocity (Stanford, CA, Stanford University Press, 2015).

106 'Assista: "Ossadas da Vala Clandestina de Perus, de 1970 a 2015”. 